\title{
Implementasi Metode Weighted Product Untuk Aplikasi Pemilihan Smartphone Android
}

\author{
Dyna Marisa Khairina ${ }^{1}$, Dio Ivando ${ }^{2}$, Septya Maharani ${ }^{3}$ \\ 1,2,3 Jurusan Ilmu Komputer, FMIPA, Universitas Mulawarman \\ 1,2,3 Jalan Barong Tongkok, Kampus Gn. Kelua, Samarinda \\ Email korespondensi : ${ }^{1}$ dyna.ilkom@gmail.com
}

Dikirim 29 Februari 2016, Diperbaiki 16 Maret 2016, Diterima 30 Maret 2016

\begin{abstract}
Abstrak - Ketidaktahuan akan kelebihan dan kekurangan smartphone android merupakan kerugian bagi user karena banyaknya pilihan smartphone android yang beredar di pasaran. Salah satu cara mengatasi masalah tersebut adalah dengan adanya suatu metode yang dapat memberikan rekomendasi sebagai bahan pertimbangan untuk pengambilan keputusan secara tepat. Penelitian bertujuan membuat aplikasi sistem pemilihan smartphone android dengan menerapkan metode Weighted Product yang dapat menyelesaikan masalah dengan cara perkalian untuk menghubungkan rating attribute dengan atribut bobot yang bersangkutan. Adapun yang menjadi kriteria dalam pertimbangan pemilihan smartphone Android dalam penelitian diperoleh dari hasil kuesioner yaitu harga, memori internal, RAM, kamera dan kapasitas baterai. Hasil dari penelitian ini berupa aplikasi sistem pemilihan smartphone android berbasis web yang dapat memberikan rekomendasi kepada user sebagai bahan pertimbangan untuk pengambilan keputusan dalam memilih smartphone android dengan menerapkan metode weighted product dalam proses analisa sistem sehingga diperoleh hasil yang terbaik dalam pengambilan keputusan.
\end{abstract}

Kata kunci - Weighted Product, Sistem Pendukung Keputusan, Smartphone, Android

Abstract - Ignorance of the advantages and disadvantages android smartphone is a loss for the user because of the large selection of android smartphone on the market. One way to overcome these problems is the presence of a method that can provide recommendations as consideration for proper decision making. The research aims to create android smartphone applications election system by applying the method of Weighted Product, which can solve the problem by means of multiplication to connect rating attributes with attribute weights are concerned. As for the criteria in the consideration of the selection of Android smartphones in the study was obtained from the results of the questionnaire that is the price, internal memory, RAM, camera and battery capacity. The results of this study in the form of electoral system applications android smartphone web based which can give recommendations to the user as consideration for decision making in choosing a smartphone android by applying weighted product in the process of systems analysis in order to obtain the best results in decision making.

Keywords - Weighted Product, Decision Support System, Smartphone, Android

\section{PENDAHULUAN}

Penggunaan ponsel lebih didominasi oleh ponsel pintar yang lebih dikenal dengan smartphone. Seiring berjalannya waktu, fungsi dasar dari ponsel biasa telah tergantikan dengan hadirnya smartphone. Ponsel pada saat ini tidak hanya berfungsi sebagai alat komunikasi telepon dan sms, namun pada saat ini ponsel lebih dikembangkan dengan berbagai aplikasi yang menarik untuk digunakan. Sebagai contohnya adalah adanya berbagai aplikasi yang menarik pada smartphone tersebut.

Penggunaan smartphone saat ini sudah semakin banyak. Smartphone tak seperti ponsel pada umumnya. Smartphone memiliki perbedaan dengan ponsel biasa, yaitu smartphone merupakan ponsel serupa komputer dengan sistem operasional yang mudah dibawa ke mana saja. Dengan adanya ponsel merupakan suatu bukti bahwa perkembangan teknologi dalam dunia mobile saat ini sudah semakin pesat.

Smartphone juga didukung oleh aplikasi-aplikasi standar seperti ponsel pada umumnya. Perbedaan dari segi tampilan, desain smartphone ini lebih inovatif dan lebih fleksibel dengan adanya fitur touchscreen atau menggunakan trackpad. Beberapa aplikasi smartphone dapat dikembangkan untuk proses pembelajaran.

Sistem operasi android ini merupakan sistem operasi untuk telepon seluler yang paling diminati oleh pengguna karena dari desain, spesifikasi dan merek yang bervariasi banyak beredar, semakin banyaknya desain, spesifikasi, dan merek smartphone 
membuat calon pengguna kesulitan untuk memilih karena banyaknya pilihan [1].

Berdasarkan uraian di atas, peneliti memandang perlunya membangun aplikasi untuk pemilihan smartphone android agar dapat memberikan rekomendasi alternatif pilihan kepada user dalam memilih smartphone android yang sesaui dengan kebutuhan dan kemampuan user. Peneliti memilih menggunakan serta menerapkan metode Weigthed Product (WP) pada penelitian ini dimana perhitungan metode ini menggunakan perkalian untuk menghubungkan rating attribute dan hanya menghasilkan nilai terbesar yang akan terpilih sebagai alternatif terbaik.

\section{TINJAUAN PUSTAKA}

\section{A. Sistem Pendukung Keputusan}

Sistem pendukung keputusan (SPK) merupakan sistem informasi interaktif yang menyediakan informasi, pemodelan, dan pemanipulasian data. Sistem ini digunakan untuk membantu pengambilan keputusan dalam situasi yang semiterstruktur dan situasi yang tidak terstruktur [2].

Tujuan dari SPK adalah untuk membantu pengambil keputusan memilih berbagai alternatif keputusan yang merupakan pengolahan informasiinformasi yang diperoleh atau tersedia dengan menggunakan model pengambilan keputusan. Ciri utama sekaligus keunggulan dari sistem pendukung keputusan tersebut adalah kemampuannya untuk menyelesaikan masalah-masalah yang tidak terstruktur [3].

Pengambilan keputusan merupakan proses pemilihan alternatif tindakan untuk mencapai tujuan atau sasaran tertentu. Pengambilan keputusan dilakukan dengan pendekatan sistematis terhadap permasalahan melalui proses pengumpulan data menjadi informasi serta ditambah dengan faktorfaktor yang perlu dipertimbangkan dalam pengambilan keputusan [4]. Tahap-tahap yang harus dilalui dalam proses pengambilan keputusan sebagai berikut.

1. Tahap Pemahaman (Intelligence Phase)

Tahap ini merupakan proses penelusuran dan pendeteksian dari lingkup problematika serta proses pengenalan masalah. Data masukan diperoleh, diproses, dan diuji dalam rangka mengidentifikasikan masalah.

\section{Tahap Perancangan (Design Phase)}

Tahap ini merupakan proses pengembangan dan pencarian alternatif tindakan atau solusi yang dapat diambil. Tersebut merupakan representasi kejadian nyata yang disederhanakan, sehingga diperlukan proses validasi dan verifikasi untuk mengetahui keakuratan model dalam meneliti masalah yang ada.

\section{Tahap Pemilihan (Choice Phase)}

Pada tahap ini dilakukan pemilihan terhadap berbagai alternatif solusi yang dimunculkan pada tahap perencanaan agar ditentukan atau dengan memperhatikan kriteria-kriteria berdasarkan tujuan yang akan dicapai.

4. Tahap Implementasi (Implementation Phase)

Pada tahap ini dilakukan penerapan terhadap rancangan sistem yang telah dibuat pada tahap perancangan serta pelaksanaan alternatif tindakan yang telah dipilih pada tahap pemilihan.

\section{B. Fuzzy Multiple Attribute Decision Making (FMADM)}

Fuzzy Multiple Attribute Decision Making (FMADM) adalah suatu metode yang digunakan untuk mencari alternatif optimal dari sejumlah alternatif dengan kriteria tertentu. Inti dari FMADM adalah menentukan nilai bobot untuk setiap atribut, kemudian dilanjutkan dengan proses perangkingan yang akan menyeleksi alternatif yang sudah diberikan [5].

Pada dasarnya, proses FMADM dilakukan melalui 3 tahap, yaitu penyusunan komponenkomponen situasi, analisis, dan sintesis informasi. Pada tahap penyusunan komponen, komponen situasi, akan dibentuk tabel taksiran yang berisi identifikasi alternatif dan spesifikasi tujuan, kriteria, dan atribut.

Tahap analisis dilakukan melalui 2 (dua) langkah. Pertama, mendatangkan taksiran dari besaran yang potensial, kemungkinan, dan ketidakpastian yang berhubungan dengan dampak-dampak yang mungkin pada setiap alternatif. Kedua, meliputi pemilihan dari preferensi pengambil keputusan untuk setiap nilai, dan ketidakpedulian terhadap resiko yang timbul. Pada langkah pertama, beberapa metode menggunakan fungsi distribusi $\left|\mathrm{p}_{\mathrm{j}}(\mathrm{x})\right|$ yang menyatakan probabilitas kumpulan atribut $\left|\mathrm{a}_{\mathrm{k}}\right|$ terhadap setiap alternatif $\left|\mathrm{A}_{\mathrm{i}}\right|$. Konsekuen juga dapat ditentukan secara langsung dari agregasi sederhana yang dilakukan pada informasi terbaik yang tersedia. Demikian pula, ada beberapa cara untuk menentukan preferensi pengambil keputusan pada setiap konsekuen yang dapat dilakukan pada langkah kedua. Metode yang paling sederhana adalah untuk menurunkan bobot atribut dan kriteria dengan fungsi utilitas atau penjumlahan terbobot.

Namun sebagian besar pendekatan FMADM dilakukan melalui 2 (dua) langkah, yaitu: pertama, melakukan agregasi terhadap keputusan-keputusan yang tanggap terhadap semua tujuan pada setiap alternatif. Sedangkan yang kedua, melakukan perangkingan alternatif-alternatif keputusan tersebut berdasarkan hasil agregasi keputusan [5].

Ada beberapa metode yang dapat digunakan dalam menyelesaikan masalah FMADM. Antara lain. 
1). Simple Additive Weighting Method (SAW)

2). Weighted Product (WP)

3). ELECTRE

4). Technique for Order Preference by Similarity to Ideal Solution (TOPSIS)

5). Analytic Hierarchy Process (AHP)

\section{Weighted Product (WP)}

Metode weighted product merupakan metode untuk menyelesaikan Multi Attribute Decision Making (MADM). Weighted Product menggunakan teknik perkalian untuk menghubungkan rating attribute, dimana rating tiap atribut harus dipangkatkan terlebih dahulu dengan atribut bobot yang bersangkutan [5]. Langkah-langkah yang dilakukan dalam penyelesaian masalah menggunakan metode Weighted Product adalah.

1. Normalisasi atau Perbaikan Bobot

$$
w_{j}=\frac{w_{j}}{\sum w_{j}}
$$

Melakukan normalisasi atau perbaikan bobot untuk menghasilkan nilai $w_{j}=1$ dimana $j=1$, $2, \ldots . ., \mathrm{n}$ adalah banyak alternatif dan $\Sigma w_{j}$ adalah jumlah keseluruhan nilai bobot.

2. Menentukan Nilai Vektor $(S)$

$S_{i}=\prod_{j-1}^{n} x_{i j} w_{j} \prod_{j-1}^{n} x_{i j} w_{j}$,

dengan $\mathrm{i}=1,2, \ldots, \mathrm{n}$

Menentukan nilai vektor (S) dengan cara mengalikan seluruh kriteria dengan alternatif hasil normalisasi atau perbaikan bobot yang berpangkat positif untuk kriteria keuntungan (benefit) dan yang berpangkat negatif untuk kriteria biaya $($ cost). Dimana $(S)$ merupakan preferensi kriteria, $(x)$ merupakan nilai kriteria dan $(n)$ merupakan banyaknya kriteria.

3. Menentukan Nilai Vektor $(V)$

$V_{i}=\frac{\prod_{j=1}^{n} x_{t j} W_{j}}{\prod_{j=1}^{n}\left(X_{j}^{v}\right) W_{j}}$, dengan $\mathrm{i}=1,2, \ldots, \mathrm{n}$

Menentukan nilai vektor $(V)$ dimana vektor $(V)$ merupakan preferensi alternatif yang akan digunakan untuk perangkingan dari masingmasing jumlah nilai vektor $(S)$ dengan jumlah seluruh nilai vektor $(S)$.

\section{METODE PENELITIAN}

\section{A. Tahap Perencanaan}

Pada tahap perencanaan ini, dikumpulkan data-data yang dibutuhkan sehingga aplikasi yang dibuat sesuai dengan kebutuhan pengguna smartphone android. Untuk memperoleh data, pada penelitian ini digunakan metode kuisioner dengan menyebarkan kuisioner kepada 50 responden pengguna smartphone android yang dibatasi hanya pada merek Samsung, Sony dan Xiaomi. Batasan masalah lain dalam penelitian ini yaitu tipe smartphone android yang digunakan yaitu tipe-tipe yang beredar pada tahun 2015. Penyebaran kuisioner dilakukan selama 5 (lima) hari, dari tanggal 19 hingga 23 Oktober 2015. Kuesioner yang diberikan kepada responden terdiri dari 2 (dua) bagian yaitu kuesioner untuk mendapatkan data mengenai kriteriakriteria yang menjadi pertimbangan pengguna saat memilih smartphone android dan kuesioner untuk mendapatkan nilai bobot kriteria. Masing-masing kriteria pada kuisioner terdapat 5 (lima) tingkat kepentingan seperti pada Tabel 1.

Tabel 1. Tingkat Kepentingan

\begin{tabular}{cc}
\hline Tingkat Kepentingan & Bobot \\
\hline Sangat Penting (SP) & 5 \\
Penting (P) & 4 \\
Cukup penting (CP) & 3 \\
Tidak Penting (TP) & 2 \\
Sangat Tidak Penting & 1 \\
\hline
\end{tabular}

\section{B. Tahap Analisis}

Dari hasil rekapitulasi kuisioner, didapat 5 (lima) kriteria yang dipertimbangkan pengguna dalam memilih smartphone android, yaitu.

1. Harga, dimana harga menjadi pertimbangan yang paling tinggi oleh pengguna smartphone android.

2. Memori internal, memori internal menjadi pertimbangan kedua setelah harga dimana pengguna mempertimbangkan besarnya kapasitas memori untuk menampung aplikasi dan file pada smartphone android.

3. RAM, kriteria yang menjadi pertimbangan ketiga dimana pengguna juga mempertimbangkan besarnya RAM pada smartphone android untuk membantu prosesor dalam bekerja. Semakin besar kapasitas RAM pada smartphone android maka akan lebih baik dan cepat performa dari kerja smartphone android tersebut.

4. Kamera utama, kriteria yang menjadi pertimbangan keempat oleh pengguna smartphone android dengan alasan semakin majunya teknologi sehingga pengguna semakin menggemari smartphone dengan tingginya kualitas dari kamera utama.

5. Kapasitas baterai, kriteria yang menjadi pertimbangan kelima oleh pengguna karena kapasitas baterai sangat berperan penting terutama untuk smartphone android dengan spesifikasi tinggi karena akan memakai konsumsi daya baterai yang juga tinggi.

Adapun gambaran singkat alur aplikasi dapat dilihat pada Gambar 1. Dimulai dari input data berupa 
ISSN : 2085-3688; e-ISSN : 2460-0997

Implementasi Metode Weighted Product Untuk Aplikasi Pemilihan Smartphone Android

kriteria yang menjadi pertimbangan dalam pemilihan smartphone android kemudian data diolah menggunakan metode weighted product untuk kemudian diperoleh hasil output berupa perangkingan nilai tertinggi pemilihan smartphone android sebagai rekomendasi alternatif terbaik.

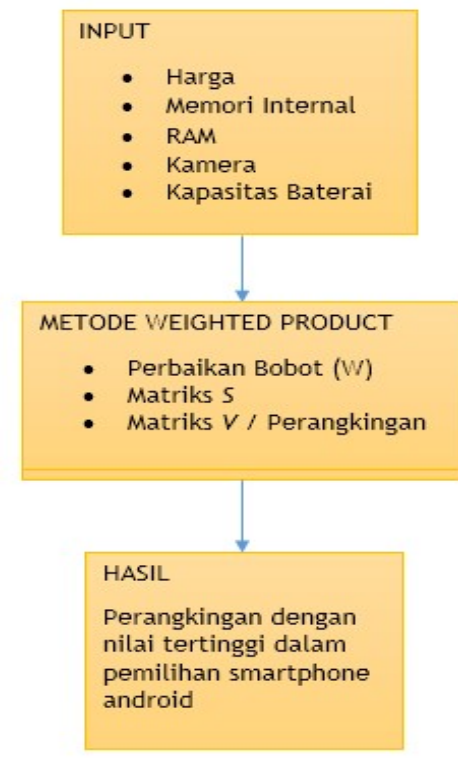

Gambar 1. Alur Aplikasi

\section{Tahap Perancangan}

Pada tahap ini, perancangan sistem menggunakan Unified Modelling Language (UML) yang menggambarkan, membangun dan pendokumentasian dari sebuah sistem yang diterapkan pada metode weighted product.

\section{Tahap Implementasi}

Pada tahap ini yang dilakukan adalah dengan menerapkan metode weighted product ke dalam program pemilihan smartphone android menggunakan bahasa pemrograman berbasis web.

\section{E. Tahap Pengujian}

Pada tahap ini dilakukan uji sistem untuk menganalisa ketepatan metode weighted product pada sistem dalam menentukan rekomendasi keputusan pemilihan smartphone android.

\section{HASIL PENELITIAN}

\section{A. Analisis Sistem}

Berdasarkan hasil rekapitulasi kuisioner, maka dibuat kriteria penilaian/bobot untuk masing-masing kriteria dengan nilai 1 (satu) sampai dengan nilai 5 (lima), seperti yang ditunjukkan pada Tabel 2 sampai Tabel 6.
Tabel 2. Kriteria Penilaian Harga

\begin{tabular}{cc}
\hline $\begin{array}{c}\text { Kriteria Penilaian / } \\
\text { Bobot Kriteria }\end{array}$ & Kriteria \\
\hline 5 & $<1.000 .000$ \\
4 & $1.000 .000-2.999 .999$ \\
3 & $3.000 .000-4.999 .999$ \\
2 & $5.000 .000-6.999 .999$ \\
1 & $>7.000 .000$ \\
\hline
\end{tabular}

Tabel 3. Kriteria Penilaian Memori Internal

\begin{tabular}{cc}
\hline $\begin{array}{c}\text { Kriteria Penilaian / } \\
\text { Bobot Kriteria }\end{array}$ & Kriteria \\
\hline 5 & $64 \mathrm{~GB}$ \\
4 & $32 \mathrm{~GB}$ \\
3 & $16 \mathrm{~GB}$ \\
2 & $8 \mathrm{~GB}$ \\
1 & $4 \mathrm{~GB}$ \\
\hline Tabel 4. Kriteria Penilaian RAM \\
\hline Kriteria Penilaian / & Kriteria \\
Bobot Kriteria & $4 \mathrm{~GB}$ \\
\hline 5 & $3 \mathrm{~GB}$ \\
4 & $2 \mathrm{~GB}$ \\
3 & $1 \mathrm{~GB}$ \\
2 & $512 \mathrm{MB}$ \\
\hline 1 &
\end{tabular}

Tabel 5. Kriteria Penilaian Kamera Utama

\begin{tabular}{cc}
\hline $\begin{array}{c}\text { Kriteria Penilaian / } \\
\text { Bobot Kriteria }\end{array}$ & Kriteria \\
\hline 5 & $>13 \mathrm{MP}$ \\
4 & $8 \mathrm{MP}$ \\
3 & $5 \mathrm{MP}$ \\
2 & $3 \mathrm{MP}$ \\
1 & $2 \mathrm{MP}$ \\
\hline
\end{tabular}

Tabel 6. Kriteria Penilaian Kapasitas Baterai

\begin{tabular}{cc}
\hline $\begin{array}{c}\text { Kriteria Penilaian / } \\
\text { Bobot Kriteria }\end{array}$ & Kriteria \\
\hline 5 & $>2500 \mathrm{mAh}$ \\
4 & $2100 \mathrm{mAh}-2500 \mathrm{mAh}$ \\
3 & $1600 \mathrm{mAh}-2000 \mathrm{mAh}$ \\
2 & $1100 \mathrm{mAh}-1500 \mathrm{mAh}$ \\
1 & $<1000 \mathrm{mAh}$ \\
\hline
\end{tabular}

Untuk proses algoritma metode weighted product dapat dilihat pada Gambar 2. 


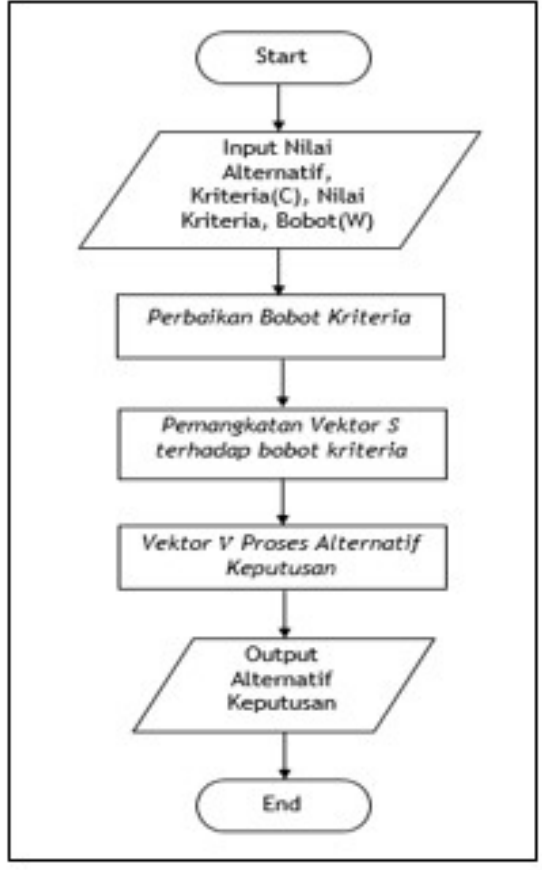

Gambar 2. Algoritma Metode Weighted Product

\section{B. Perancangan Sistem}

Perancangan sistem merupakan proses pengembangan sistem setelah data yang didapat cukup untuk melakukan analisa sistem untuk menunjang pengembangan sistem pemilihan smartphone android.

\section{Perancangan Arsitektur Sistem}

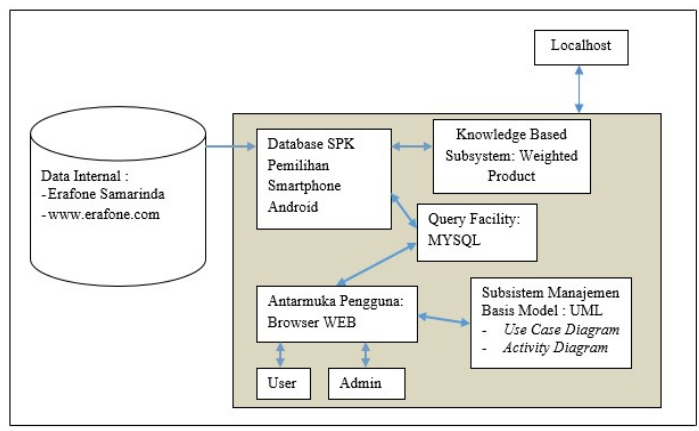

Gambar 3. Arsitektur SPK Pemilihan Smartphone Android

Gambar 3 menunjukan arsitektur sistem pendukung keputusan pemilihan smartphone android yang dibangun. Data yang dibutuhkan berdasarkan dari sumber internal, yaitu dari erafone, www.erafone.com. Selanjutnya data tersebut dimasukkan ke dalam database sistem pendukung keputusan pemilihan smartphone android. Manajemen database pada sistem ini menggunakan MySQL. Sistem manajemen model menggunakan UML (Unified Modelling Language) untuk merancang model sistem yang dibangun. Untuk proses komunikasi user dan admin melakukan interaksi dengan sistem menggunakan browser web.

2. Perancangan Use Case Diagram

Use Case Diagram digambarkan pada Gambar 4 dimana menjelaskan kegiatan yang dilakukan oleh admin dan user pada sistem yang dibuat. User sebagai pengguna yang akan memilih smartphone android berdasarkan kriteria-kriteria yang telah ditetapkan pada sistem. Sedangkan admin berfungsi sebagai pengelola data dan informasi pada sistem.

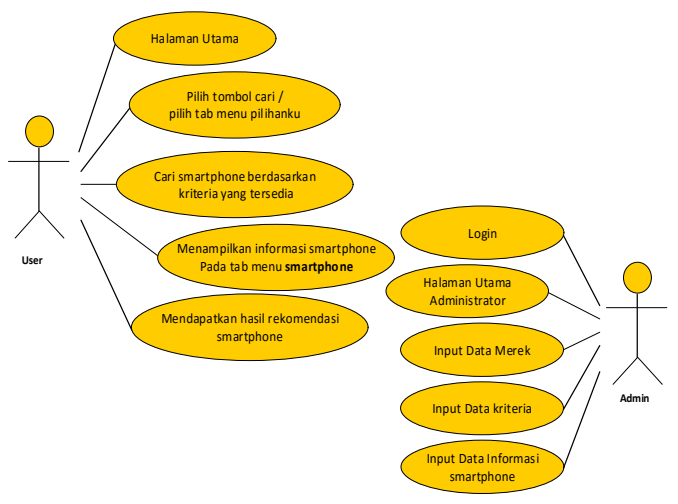

Gambar 4. Use Case Diagram Sistem

3. Perancangan Activity Diagram

a) Activity Diagram User

Activity diagram user menjelaskan mengenai alur-alur kegiatan yang dilakukan oleh user terhadap sistem yang dibangun. Bagaimana masing-masing alir berawal, decision yang mungkin terjadi, dan bagaimana masing-masing alir berakhir. Gambar 5 membahas mengenai aktivitas $u$ ser.

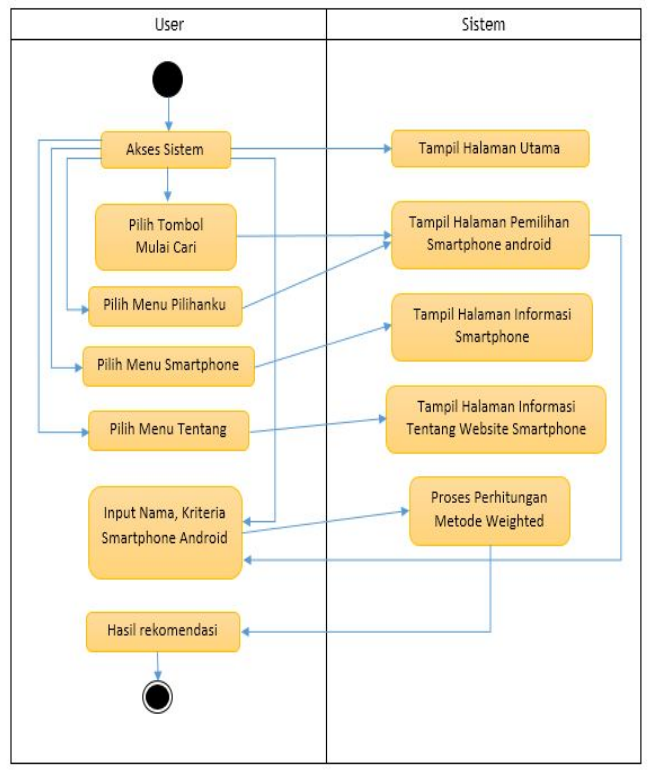

Gambar 5. Activity Diagram User 


\section{b) Activity Diagram Admin}

Activity diagram admin dapat dilihat pada Gambar 6 yang menjelaskan mengenai alur-alur kegiatan yang dilakukan oleh admin terhadap sistem yang dibangun. Bagaimana masing-masing alir berawal, decision yang mungkin terjadi, dan bagaimana masing-masing alir berakhir.

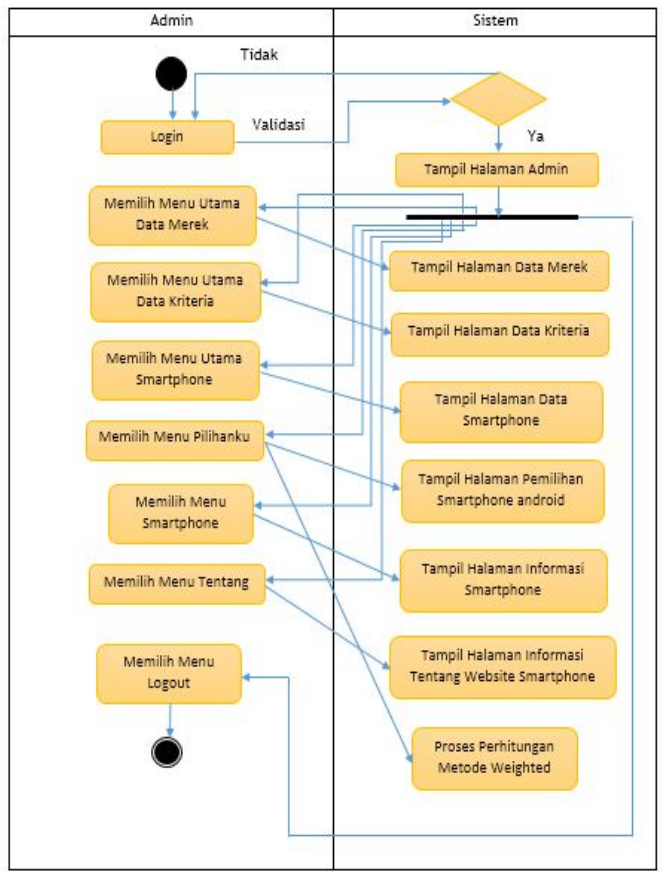

Gambar 6. Activity Diagram Admin

\section{Implementasi Sistem}

Gambar 7 menampilkan halaman awal dari aplikasi pemilihan smartphone android. Sedangkan Gambar 8 menampilkan halaman menu untuk user memilih tingkat kepentingan dari tiap-tiap kriteria dalam memilih smartphone android.

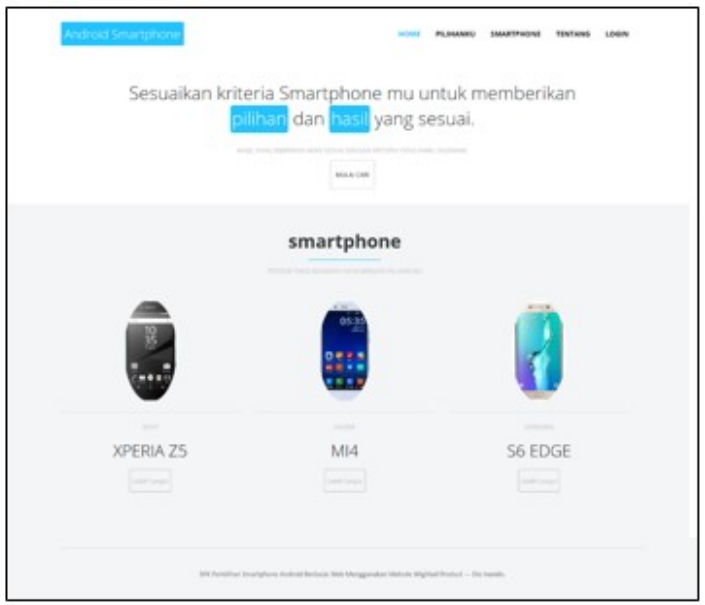

Gambar 7. Halaman Awal Sistem

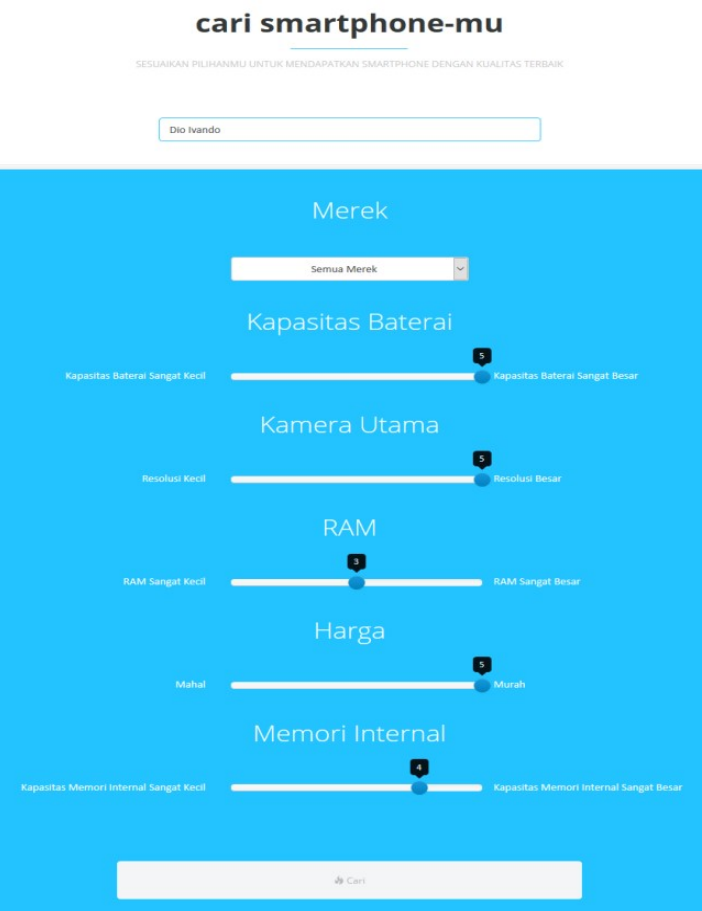

Gambar 8. Halaman Input Kriteria Pemilihan

Pada Gambar 8 user memilih tingkat kepentingan dari masing-masing kriteria dalam memilih smartphone android berdasarkan kebutuhan dan keinginan user. Hasil input data dari user kemudian data tersebut diolah dan dihitung dengan menggunakan metode weighted product sehingga menghasilkan rekomendasi smartphone android beserta detail informasi smartphone android tersebut berdasarkan nilai perhitungan tertinggi dari metode weighted product. Hasil rekomendasi ouput dapat dilihat pada Gambar 9 dimana berdasarkan pilihan tingkat kepentingan dari masing-masing kriteria dalam memilih smartphone android oleh user pada Gambar 8 sehingga dihasilkan rekomendasi smartphone android yang disarankan tertinggi adalah Xiaomi Mi Note, kemudian rekomendasi kedua dan ketiga adalah Sony Xperia Z5 dan Samsung S6 Edge dengan keputusan akhir tetap ada pada pengguna. 


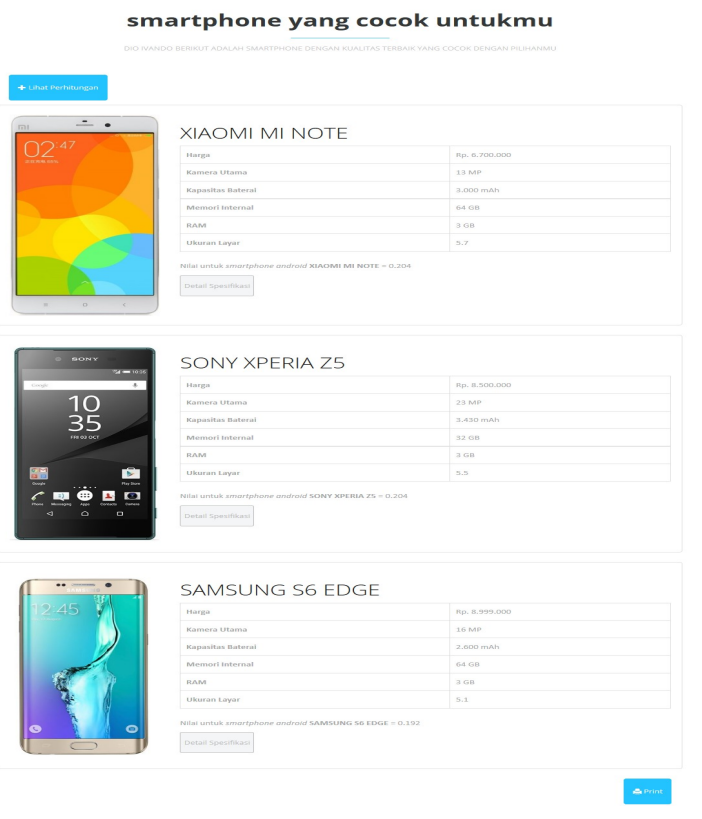

Gambar 9. Halaman Rekomendasi Smartphone Android yang Telah Diproses Sistem

\section{Pengujian}

Pengujian dilakukan sebagai simulasi untuk mengetahui apakah hasil perhitungan metode weighted product pada sistem sama dengan hasil perhitungan manual. Pengujian dilakukan menggunakan data yang sama pada sistem. Diberikan data uji berupa 3 (tiga) kriteria smartphone android dan 5 (lima) alternatif yang akan menjadi alternatif rekomendasi keputusan yaitu.

- $\mathrm{A} 1=$ MI Note

- $\mathrm{A} 2=$ Xperia Z5

- $\mathrm{A} 3$ = S6 EDGE

Terdapat 5 (lima) kriteria yang jadi acuan dalam pengambilan keputusan.

- $\mathrm{C} 1=$ Kapasitas Baterai

- $\quad \mathrm{C} 2=$ Kamera Utama

- $\mathrm{C} 3=\mathrm{RAM}$

- $\mathrm{C} 4=$ Harga

- $\quad$ C5 = Memori Internal

Berdasarkan kriteria penilaian dari masingmasing parameter kriteria pada Tabel 2 hingga Tabel 6 , maka didapat nilai untuk setiap alternatif kriteria yang dapat dilihat pada Tabel 7.

Tabel 7. Nilai Untuk Setiap Alternatif Kriteria

\begin{tabular}{cccccc}
\hline \multirow{2}{*}{ Alternatif } & \multicolumn{5}{c}{ Kriteria } \\
\cline { 2 - 6 } & C1 & C2 & C3 & C4 & C5 \\
\hline A1 & 3080 & 13 & 3 & 2.800 .000 & 16 \\
A2 & 3100 & 21 & 3 & 8.500 .000 & 16 \\
A3 & 2600 & 16 & 3 & 12.300 .000 & 16 \\
\hline
\end{tabular}

Dari Tabel 7 dilakukan perbaikan bobot terlebih dahulu. Bobot preferensi yang dijadikan pengujian didapat dari hasil kusioner dimana user memilih tingkat kepentingan sesuai dengan kebutuhan yang sesuai dalam melakukan pemilihan smartphone android.

Tabel 8. Nilai Bobot Untuk Setiap Kriteria

\begin{tabular}{ccc}
\hline Kriteria & Nilai Bobot & Tingkat Kepentingan \\
\hline C1 & 5 & Sangat Penting \\
C2 & 5 & Sangat Penting \\
C3 & 3 & Cukup Penting \\
C4 & 5 & Sangat Penting \\
C5 & 4 & Penting \\
\hline
\end{tabular}

Tabel 8 merupakan simulasi nilai bobot untuk setiap kriteria yang dicocokkan dengan sistem saat user memilih tingkat kepentingan dari masing-masing kriteria, yaitu Harga (sangat penting) dengan bobot 5, Memori Internal (sangat penting) dengan bobot 5, RAM (cukup penting) dengan Bobot 3, Kamera (sangat penting) dengan bobot 5 dan Kapasitas Baterai (penting) dengan bobot 4. Dari bobot tersebut kemudian dilakukan normalisasi bobot/perbaikan bobot, menentukan vektor S (preferensi kriteria) dan terakhir mencari nilai vektor $\mathrm{V}$ (preferensi alternatif) yang akan digunakan untuk perangkingan alternatif.

1. Perbaikan Bobot atau Normalisasi

$$
\begin{aligned}
& w_{1}=\frac{5}{5+5+3+5+4}=\frac{5}{22}=0.227 \\
& w_{2}=\frac{5}{5+5+3+5+4}=\frac{5}{22}=0.227 \\
& w_{3}=\frac{3}{5+5+3+5+4}=\frac{3}{22}=0.136 \\
& w_{4}=\frac{5}{5 ! 5 ! 3 ! 5 ! 4}=\frac{5}{22}=0.227 \\
& w_{5}=\frac{4}{5+5+3+5+4}=\frac{4}{22}=0.182
\end{aligned}
$$

\section{Menentukan Vektor $S$}

$$
\begin{aligned}
S_{1} & =\left(3030^{0.227}\right)\left(13^{0.227}\right)\left(3^{0.126}\right)\left(2800000^{-0.227}\right)\left(16^{0.192}\right) \\
& =(6.193)(1.790)(1.161)(0.034)(1.656) \\
& =0.725 \\
S_{2} & =\left(3100^{0.227}\right)\left(21^{0.227}\right)\left(3^{0.136}\right)\left(8505000^{-0.227}\right)\left(16^{0.192}\right) \\
& =(6.202)(1.989)(1.161)(0.027)(1.656) \\
& =0.640 \\
S_{2}= & \left(2600^{0.227}\right)\left(16^{0.227}\right)\left(3^{0.136}\right)\left(12300000^{-0.227}\right)\left(16^{0.192}\right) \\
& =(5.959)(1.876)(1.161)(0.025)(1.656) \\
& =0.537
\end{aligned}
$$

\section{Menentukan Vektor V}

$$
\begin{aligned}
v_{1} & =\frac{0.725}{0.725+0.640+0.537+0.516+0.564+0.442 .} \\
& =\frac{0.72 \mathrm{E}}{3.434} \\
& =0.212
\end{aligned}
$$




$$
\begin{aligned}
v_{2} & =\frac{0.640}{0.725+0.640+0.537+0.516+0.564+0.142} \\
& =\frac{0.64 \mathrm{C}}{3.434} \\
& =0.187 \\
v_{3} & =0.725+0.640+0.537+0.516+0.564+0.442 \\
& =\frac{0.537}{3.434} \\
& =0.157
\end{aligned}
$$

Dari hasil nilai vektor $\mathrm{V}$ yang diperoleh, maka rekomendasi alternatif yang didapat dari hasil perangkingan adalah nilai $\mathrm{V}_{1}$ yang memiliki nilai tertinggi yaitu 0.212 , sehingga sistem merekomendasikan smartphone android yang sesuai pilihan user yaitu Mi Note sebagai alternatif pertama. Untuk lebih jelasnya hasil perangkingan rekomendasi smartphone android dari data uji dapat dilihat pada Tabel 9.

Tabel 9. Hasil Perangkingan Rekomendasi

\begin{tabular}{ccc}
\hline $\begin{array}{c}\text { Rangking } \\
\text { Alternatif }\end{array}$ & $\begin{array}{c}\text { Smartphone } \\
\text { Android }\end{array}$ & Nilai Akhir (Vektor V) \\
\hline 1 & Mi Note & $\mathbf{0 . 2 1 2}$ \\
2 & Xperia Z5 & $\mathbf{0 . 1 8 7}$ \\
3 & S6 EDGE & $\mathbf{0 . 1 5 7}$ \\
\hline
\end{tabular}

\section{PENUTUP}

\section{A. Kesimpulan}

Berdasarkan hasil penelitian yang telah dilakukan dapat diambil kesimpulan bahwa untuk proses pemilihan smartphone android dibutuhkan beberapa kriteria sebagai pertimbangan. Adapun kriteria yang diperoleh dari hasil kuisioner yaitu harga, memori internal, RAM, kamera, dan kapasitas baterai. Dari beberapa kriteria tersebut kemudian diolah dengan mengimplementasikan metode Weighted Product sebagai perhitungannya yang menggunakan perkalian untuk menghubungkan rating attribute dan menghasilkan nilai terbesar yang akan terpilih sebagai alternatif terbaik. Hasil pengujian perhitungan metode Weighted Product pada simulasi data yang diuji coba menunjukkan bahwa perangkingan nilai vektor $\mathrm{V}$ yang terbesar/tertinggi yang menjadi alternatif smartphone android terbaik berdasarkan masukan dari tingkat kepentingan kriteria oleh user.

\section{B. Saran}

Penelitian selanjutnya dapat mengembangkan aplikasi yang telah dibuat ini dengan penambahan kriteria-kriteria lain sebagai pertimbangan dalam memilih smartphone android serta penambahan interface yang lebih baik. Aplikasi juga dapat dikembangkan dengan penerapan metode lainnya sebagai pembanding dan dapat dijadikan model pengembangan sistem yang lebih baik.

\section{DAFTAR PUSTAKA}

[1] Gunawan, \& Astuti, S, "Sistem Pendukung Keputusan Pemilihan Gadget Android Menggunakan Metode Promethee," Techno COM, Vol. 12, No. 2, Mei 2013, pp. 104-116.

[2] Kusrini, Konsep dan Aplikasi Sistem Pendukung Keputusan. Yogyakarta: Andi, 2007.

[3] Subakti, I, Sistem Pendukung Keputusan (Decision Support System). Surabaya: ITS, 2002.

[4] Kadarsah, Suryadi dan M. Ali Ramdani, Sistem Pendukung Keputusan: Suatu Wacana Struktural Idealisasi dan Implementasi Konsep Pengambilan Keputusan. Bandung: Remaja Rosdakarya, 2002.

[5] Kusumadewi, Sri, Hartati, S, Harjoko, A, dan Wardoyo, R, Fuzzy Multi Attribute Decision Making. Yogyakarta: Graha Ilmu, 2006. 